\title{
Study on Strength Properties of Basalt Fibre Reinforced Concrete with Partial Replacement of Cement as Metakolic
}

\author{
M.Kalaivani ${ }^{1 *}$, R.Jagadeesan ${ }^{1}$, P.Mageshkumar ${ }^{1}$, K.Angusenthil ${ }^{2}$ \\ ${ }^{I}$ Assistant Professor, K.S.Rangasamy College of Technology, Tiruchengode-637215, Tamil Nadu, India. \\ ${ }^{2}$ N-PDF (SERB), K.S.Rangasamy College of Technology, Tiruchengode-637215, Tamil Nadu, India. \\ *Corresponding author E-Mail ID: mkalaivani85@gmail.com \\ Doi: https://doi.org/10.34256/irjmtcon50
}

\begin{abstract}
This paper provides a summary of strength properties of basalt fibre reinforced concrete. It contains short discrete fibres that uniformly distributed and randomly oriented. Basalt fibres are in increasing demand as they improve the tensile resistance and ductile performance of plain concrete, thus reducing cracking and leading to improve durability of reinforced concrete structure. The main objective is to investigate the mechanical properties of basalt fibre reinforced concrete containing met kaolin as partial replacement of cement. The fibres were placed in concrete by $0.3 \%, 0.4 \%$ and $0.5 \%$ of its total volume of concrete, for each mix $10 \%$ of cement is replaced by met kaolin. Three sets of cubes, cylinders and prisms for each mix of $\mathrm{M}_{20}$ grade concrete were casted and tested after 28 days of curing. Experimental results showed that the addition of basalt fibres up to $0.4 \%$ fibre volume together with mineral admixtures improved the strength properties of concrete.
\end{abstract}

Keywords: Basalt Fibre, Metakolin, strength, ductility, Mineral admixture, Mechanical Property

\section{INTRODUCTION}

The amount of fibres added to a concrete mix is expressed as a percentage of the total volume of composite termed "volume fraction" ranges from 0.1 to $3 \%$. The aspect ratio (1/d) is calculated by dividing fibre length by its diameter. Fibres with a non-circular cross section use an equivalent diameter for the calculation of aspect ratio. If the fibre's modulus of elasticity is higher than the matrix, they help to carry the load by increasing the tensile strength of the material. Increasing the aspect ratio of the fibre usually segments the flexural strength and toughness of the matrix. However, fibres that are too long tend to ball in the mix and create workability problems. Fibres like steel, glass, basalt, polypropylene, nylon etc are used to improve the properties of concrete.

\section{LITERATURE REVIEW}

Fathimairine (2014) investigated and compared the strength of basalt fibre reinforced concrete with M30 grade of concrete. Three different basalt fibre contents were chosen $1 \mathrm{~kg} / \mathrm{m} 3$, $2 \mathrm{~kg} / \mathrm{m} 3$ and $4 \mathrm{~kg} / \mathrm{m} 3$ for each mix. Super plasticizer of $0.3 \%$ was used to increase the workability of the concrete. The compressive, split tensile and flexural strength of basalt fibre were increased by $14 \%, 62 \%$ and $54 \%$ at $4 \mathrm{~kg} / \mathrm{m} 3$ of basalt fibre content. It was observed that, the percentage increase in the strength of basalt reinforced concrete increases with the age of concrete. It also acts 
as the crack arrestors. They also reduce the permeability of concrete and thus reduce bleeding of water.

Tehminaayub et.al. (2013) examined three mixes of 1, 2 and $3 \%$ of basalt fibre, with $10 \%$ of cement as replaced with silica fume and another mix prepared by $10 \%$ of metakaolin as cement replacement. Experimental results concluded that optimum use of basalt fibre will only increase the strength of concrete. If it exceed a particular level leads to decrease in strength of concrete. In compressive test, $2 \%$ of basalt concrete gave the highest value than the $3 \%$ basalt fibre concrete containing silica fume as replacement. In splitting tensile strength also there was a better increase, where $3 \%$ basalt concrete showed $36.24 \%$ increase in strength than the plain concrete.

Geethanjali et.al. (2014) showed that super plasticizers provide better dispersion of cement particle and also provide better workability. In this paper, the effect of inclusion of basalt fibre and super plasticizers on the compressive, flexural strength of fibre reinforced concrete was studied. The experimental test results demonstrated at considerable increase in compression, flexural of specimen at 3,7 and 28 days with addition of basalt fibre and super plasticizers. It was observed that, the percentage increase in the strength of basalt reinforced concrete, super plasticizers added concrete increase with the age of concrete. It also showed that the presence of fibre in concrete acts as the crack arrestors. The ductility characteristics have improved with the addition of basalt fibre. The failure of fibre concrete was gradual as compared to that of brittle failure of plain concrete. When basalt was contacted with other chemicals they produce no chemical reactions that may damage health or the environment.

Vikassrivastava et.al. (2012) conducted metakaolin and silica fume together as a replacement of cement to increase the strength properties of the concrete. The experimental investigations were carried out to find the suitability of silica fume and metakaolin combination in production of concrete. The optimum doses of silica fume and metakaolin in combination were found to be $6 \%$ and $15 \%$ respectively, when used as part replacement of ordinary portland cement Both the silica fume and metakaolin are useful pozzolanic materials. The replacement levels were $5 \%, 6 \%, 7 \%, 8 \%, 9 \%$ and $10 \%$ for silica fume and 10\%, 15\%, 20\% and $25 \%$ for metakaolin. The 28 day compressive strength of concrete generally increase with the metakaolin content up to its optimum content, at all the silica fume contents, and thereafter declines. The 28 day compressive strength of concrete generally increase with the metakaolin content up to its optimum content, at all the silica fume contents, and thereafter declines. The slump was found to decrease with increase in metakaolin content at all the silica fume contents considerably.

Mustapha Abdulhadi (2014) resulted that the compressive strength for C30 grade of concrete with basalt and polypropylene fibre at different volume fraction showed gradual degree of reduction. Addition of $0.3 \%, 0.6 \%, 0.9 \%$ and $1.2 \%$ resulted in a decrease of compressive strength relative to plain concrete by $9 \%, 19 \%, 1 \%$, and $18 \%$ respectively. It was also observed that the incorporation of fibres in the concrete matrix greatly increases splitting tensile strength. Addition of $0.3 \%$ and $0.6 \%$ volume of basalt fibre increase splitting tensile strength by $2.6 \%$ and $22.9 \%$ also, addition of $0.3 \%, 0.6 \%$ and $0.9 \%$, volume of polypropylene fibre increase the splitting tensile strength of concrete by $15.1 \%, 7.8 \%$ and $5.6 \%$ respectively.

Nova John (2013) presented a study about the Supplementary Cementitious Materials (SCMs) that have been widely used all over the world in concrete due to their economic and environmental benefits. Metakaolin was also one of non-conventional material which can be used beneficially in the construction industry. The replacement levels were 5\%,10\%, 15\% and 20\% (by weight) for metakaolin. The inclusion of metakaolin results in faster early age strength development of concrete. Mix with $15 \%$ metakaolin was superior to all other mix. The results encourage the use of metakaolin, as pozzolanic material for partial cement replacement in 
producing high strength concrete. Inclusion of metakaolin severs as an invaluable means to protect environment resources, which may result in more viable constructions in the future.

Gore Ketan and Suhasini (2012) evaluated the performance of High Strength Concrete (HSC) containing supplementary cementations materials. Here cement was replaced in percentages of $0 \%, 1 \%, 1.5 \%, 2 \%$ with basalt fibre. The result showed that addition of fibre in high strength concrete, the strength decreased on 7 days and 14 days. The workability of high performance concrete was increased using the super plasticizer conplast SP 430. The strength of basalt fibre would be more than the design mix after 28 days. Basalt rock fibres have no toxic reaction with air or water, also non-combustible and explosion proof. When in contact with other chemicals they produce no chemical reactions that may damage health or the environment. The cost of basalt fibre was considerable lower than that of similar materials.

Beulah and Prahallada (2012) conducted an experimental investigation on the effect of partial replacement of cement by metakaolin by various percentages via $0 \%, 10 \%, 20 \%$, and $30 \%$ on the properties of high performance concrete, when it is subjected to hydrochloric acid attack. It concluded that the compressive strength of HPC mixes decreases with increasing water binder ratio. The results indicated that use of replacement cement by metakaolin in HPC has improved performance of concrete up to $10 \%$. It concluded that the addition of metakaolin increases the resistance to acid attack of HPC. It also concluded that for $10 \%$ metakaolin based HPC, the weight loss due to acid attack is minimum.

Ranjitsinhk et.al. (2014) carried out a comparative study of effect basalt, glass and steel fibre on compressive and flexural strength of M40 grade concrete. The fibres were placed in concrete randomly by $(0.25 \%, 0.5 \%, 0.75 \%, 1 \%)$ of its total volume of concrete. The tensile strength of the concrete is very low because plain concrete normally contains numerous micro cracks. The control beam had a load at yielding of $70 \mathrm{kN}$ and an ultimate load of $88 \mathrm{kN}$. The initial cracks were initiated at a load of $40 \mathrm{kN}$ and progressed towards upwards direction from bottom. The results showed that maximum compressive strength is obtained for $0.5 \%$ for every fibre and among these three fibres basalt fibre has got the maximum compressive and flexural strength for $0.5 \%$.

\section{Experimental Investigation}

OPC 43 (Ordinary Portland cement) grade cement of Specific gravity 3.15 was used. River sand passing the $4.75 \mathrm{~mm}$ sieve and predominantly retained on the $75 \mu \mathrm{m}$ sieve. Locally available quarry stone in good strength passing through $20 \mathrm{~mm}$ and retain in $10 \mathrm{~mm}$ sieve. Portable water can also be used for making the concrete. Conplast SP 430 can be used as superplasticizer. Metakaolin is a pozzolanic material which is manufactured from selected kaolins, after refinement and calcinations under specific conditions. Here $10 \%$ of metakaolin is added as a partial replacement of cement. Basalt fibre originates from volcanic magma and volcanoes, a very hot fluid or semi fluid material under the earth's crust, solidified in the open air. The molten rock is then extruded through small nozzles to produce continuous filaments of basalt fibre. Basalt rock fibres have no toxic reaction with air or water, also non-combustible and explosion proof. When in contact with other chemicals they produce no chemical reaction that may damage health or the environment.

Table 1. Mechanical Properties of concrete

\begin{tabular}{|c|c|c|c|c|}
\hline S. No. & Basalt fibre & $\begin{array}{c}\text { Compressive } \\
\text { Strength } \mathrm{N} / \mathrm{mm}^{2}\end{array}$ & $\begin{array}{c}\text { Split tensile strength } \\
\mathrm{N} / \mathrm{mm}^{2}\end{array}$ & $\begin{array}{c}\text { Flexural strength } \\
\mathrm{N} / \mathrm{mm}^{2}\end{array}$ \\
\hline 1. & $0 \%$ & 2.2 & 2.57 & 3.5 \\
\hline
\end{tabular}




\begin{tabular}{|c|c|c|c|c|}
\hline 2. & $0.3 \%$ & 28.9 & 3.1 & 3.9 \\
\hline 3. & $\mathbf{0 . 4 \%}$ & $\mathbf{3 0 . 1}$ & $\mathbf{3 . 3}$ & $\mathbf{4 . 3}$ \\
\hline 4. & $0.5 \%$ & 27.9 & 2.9 & 3.7 \\
\hline
\end{tabular}

The fibres used in study were of $18 \mu \mathrm{m}$ in diameter and $24 \mathrm{~mm}$ in length. $\mathrm{M}_{20}$ grade of concrete had been designed as per IS 10262-2009 code and design was shown in Annexure-I. Mix proportion derived for the $\mathrm{M}_{20}$ grade concrete with a w/c ratio of 0.45 is 1:2.11:3.92:0.45. The cube, Cylinder and Prism specimens are cast for standard dimensions and curing will be done for 28 days. The experimental result are shown in Table 1.

\section{CONCLUSION}

Based on the test results of the experimental investigation, the following conclusions were drawn:

1. The workability of the concrete was increased by using the super plasticizer.

2. The maximum compressive strength for the fibre reinforced concrete cube was obtained as $30.1 \mathrm{~N} / \mathrm{mm}^{2}$, whereas for the conventional specimen the strength was $25.8 \mathrm{~N} / \mathrm{mm}^{2}$.

3. The compressive strength of basalt FRC was $16.6 \%$ more than that of conventional specimen.

4. The maximum split tensile strength of the fibre reinforced concrete cylinder was obtained as $3.3 \mathrm{~N} / \mathrm{mm}^{2}$, whereas for the conventional specimen the strength was $2.32 \mathrm{~N} / \mathrm{mm}^{2}$

5. The split tensile strength of basalt FRC was $42.2 \%$ more than that of conventional specimen.

6. The maximum flexural strength of the fibre reinforced concrete obtained was $4.3 \mathrm{~N} / \mathrm{mm}^{2}$, whereas for the conventional specimen the strength was $3.15 \mathrm{~N} / \mathrm{mm}^{2}$.

7. The flexural strength of basalt FRC was $36.5 \%$ more than that of conventional specimen.

8. From the experimental results, the optimum dosage of basalt fibre content was $2 \%$ by its volume of concrete for $\mathrm{M}_{20}$ grade of concrete.

9. In general it is concluded that the basalt fibre concrete gives better strength than the conventional concrete.

\section{REFERENCES}

1. Fathimairine.I.A. (2014) "Strength Aspects of Basalt Fibre Reinforced Concrete"International Journal of Innovative Research in Advanced Engineering,Vol.1, pp.192-198.

2. Tehminaayub, Nasirshafiq and Fadhilnuruddin.M. (2013) "Mechanical Properties of HighPerformance Concrete Reinforced with Basalt Fibres", Vol. 3, pp. 131-139.

3. Geethanjalig.K,Mohinder.R and Chandraraj. (2014) "Deformation Characteristics of Basalt Reinforced Concrete with Super plasticizer" IOSR Journal of Mechanical and Civil Engineering, Vol. 1, pp. 05-11.

4. Vikassrivastava, Rakesh Kumar, Agarwal.V.C and Mehta.P.K. (2012) "Effect of Silica Fume and Metakaolin combination on Concrete" International Journal of Civil and Structural Engineering, Vol. 2, pp. 893-900.

5. Mustapha Abdulhadi (2014) "A Comparative Study of Basalt and Polypropylene Fibre Reinforced Concrete on Compressive and Tensile behaviour" International Journal of Engineering Trends and Technology, Vol. 9, pp. 97-112. 
6. Nova John (2013) "Strength Properties of Metakaolin Admixed Concrete" International Journal of Scientific and Research Publications, Vol. 3, pp. 1-7.

7. Niveditha.A and Manivel.S. (2014) "Effects of Partial Replacement of Cement by Metakaolin in SIFCON" International Journal of Engineering and Management Research, Vol. 4, pp. 100-103.

8. Gore Ketan.R and Suhasini. (2012) "The Performance of Basalt Fibre in High Strength Concrete" Journal of Information, Knowledge and Research in Civil Engineering, Vol. 2, pp. 117-124.

9. Beulah.M and Prahallada.M.C. (2012) "Effect of Replacement of Cement by Metakaolin on The Properties of High Performance Concrete subjected to Hydrochloric Acid Attack" International Journal of Engineering and Research and Applications, Vol. 2, pp. 33-38.

10. Ranjitsinh.K,PatilandKulkarni.D.B.(2014) "Comparative Study of Effect of Basalt, Glass and Steel Fibre on Compressive and Flexural Strength of Concrete" International Journal of Research in Engineering and Technology, Vol. 3, pp. 436-438.

11. Sanjay.N., Patil, Anil.K., Gupta, Subhash. Sand Deshpande."MetakaolinPozzolanic Material for Cement in High Strength Concrete" IOSR Journal of Mechanical and Civil Engineering, ISSN. 2278-1684, pp. 46-49.

12. Devi.M. (2015) "Implication of Metakaolin in Quarry Dust Concrete" International Journal of Civil and Structural Engineering Research, Vol. 4, pp. 171-174.

13. Joshi A.A., Rangari.S.M and Shitole.A.D. (2014) "The Use of Basalt Fibre to Improve the Flexural Strength of Concrete Beam" International Journal of Innovative Science, Engineering and Technology, Vol. 1, pp. 612-614.

14. David Garcia, Pello Alonso, Jose-Tomas San-Jose and Garmendia, (2010) "Confinement of Medium Strength Concrete Cylinders with Basalt Textile Reinforced Mortar",13th International Congress on Polymers in Concrete, pp.506-518.

15. ChaohuaJiang, Ke Fan, Fei Wu and Da Chan., (2014) "Experimental Study on the Mechanical Properties and Microstructure of Chopped Basalt Fibre Reinforced Concrete”, Material and Design, Vol.58, pp. 187-193.

16. Kunalsingha (2012) "A Short Review on Basalt Fibre", International Journal of Textile Science, pp. 19-28. 